\section{Determination of the Optimal Rate of Slow-release Fertilizer for Enhanced Growth of Pawpaw Seedlings in Containers}

\author{
Kirk W. Pomper, ${ }^{1}$ \\ Desmond R. Layne, ${ }^{2}$ and \\ Eddie B. Reed ${ }^{3}$
}

Additional index words. Asimina triloba, root:shoot ratio, kentucky banana

Summary. Growth of pawpaw (Asimina triloba) seedlings in containers was examined in a factorial greenhouse experiment with four treatment levels of the slow-release fertilizer, Osmocote 14-14-14 (14N6.1P-11.6K), incorporated in ProMix BX potting substrate at $0,0.13$, 0.26 or $0.81 \mathrm{~kg} \cdot \mathrm{m}^{-3}(0,0.22,0.44$, or $1.37 \mathrm{lb} / \mathrm{yard}^{3}$ ) and three treatment levels of liquid-feed fertilizer of Peters 20-20-20 (20N-8.7P-16.6K) watersoluble fertilizer at 0,250 , or 500 $\mathrm{mg} \cdot \mathrm{L}^{-1}(\mathrm{ppm})$. When plants were harvested 18 weeks after sowing, seedlings subjected to the highest rate of Osmocote 14-14-14 at $0.81 \mathrm{~kg} \cdot \mathrm{m}^{-3}$ and liquid-feed at $500 \mathrm{mg} \cdot \mathrm{L}^{-1}$ had the greatest total biomass, about 3 -fold greater than nonfertilized plants. In a separate greenhouse experiment, growth of seedlings was examined

Kentucky State University, Land Grant Program, 129 Atwood Research Facility, Frankfort, KY 40601-2355.

This research was supported by U.S. Dept. of Agriculture, Cooperative State Research, Education, and Ex tension Service Agreement no. KYX-10-97-28P. We thank R. Neal Peterson (founder of The PawPaw Foundation) for supplying seed used in this study. The technical assistance of S. Jones is also gratefully acknowledged by the authors.

${ }^{1}$ Principal investigator of horticulture and curator, USDA National Clonal Germplasm Repository for Asimina sp., Kentucky State University, and president of The PawPaw Foundation. Towhom reprint requests should be addressed.

${ }^{2}$ Assistant professor of pomology and extension fruit specialist, Dept. of Horticulture, Box 340375, Clemson Univ., Clemson, SC 29634-0375.

${ }^{3}$ Research assistant, Horticulture Program, Kentucky State University. with Osmocote 14-14-14 as the sole fertilizer source at six treatment levels of: $0,0.81,2.22,4.43,8.86$, or 17.7 $\mathrm{kg} \cdot \mathrm{m}^{-3}(0,1.37,3.74,7.47,14.9$, or $\left.29.9 \mathrm{lb} / \mathrm{yard}^{3}\right)$. Early seedling growth was hastened in the $2.22 \mathrm{~kg} \cdot \mathrm{m}^{-3}$ treatment rate, but delayed in $\mathbf{1 7 . 7}$ $\mathrm{kg} \cdot \mathrm{m}^{-3}$ treatment rate, when compared to nonfertilized control plants. When seedlings were harvested 17 weeks after sowing, plants had the greatest shoot, root, and total dry weight with Osmocote 14-14-14 at a rate of 2.22 $\mathrm{kg} \cdot \mathrm{m}^{-3}$. Root:shoot ratio decreased from about 1.5 without Osmocote 14-14-14, to about 0.65 at rates of $2.22 \mathrm{~kg} \cdot \mathrm{m}^{-3}$ or greater. Based on the results of this study, the slow-release fertilizer, Osmocote 14-14-14, can be used effectively as a sole fertilizer source when incorporated into potting substrate at a rate of $\mathbf{2 . 2 2}$ $\mathrm{kg} \cdot \mathrm{m}^{-3}$ or at a reduced rate of 0.81 $\mathrm{kg} \cdot \mathrm{m}^{-3}$ when supplemented with weekly applications of liquid-feed fertilizer at a rate of $500 \mathrm{mg} \cdot \mathrm{L}^{-1}$ of Peters 20-20-20, to enhance production of container-grown pawpaw seedlings.

\section{$\mathrm{T}$} he North American pawpaw has potential as a highvalue tree-fruit crop or as a landscape component (Layne, 1996; Pomper et al., 1999). Historically, pawpaws have been difficult to propagate. Pawpaws develop a strong taproot with a fragile root system, which can be easily damaged upon digging; therefore, most commercial nurseries in the United States propagate their own pawpaw trees in containers (unpublished). Although this results in a significantly greater cost to the purchaser, trees usually have a strong, healthy root system for field establishment. Unfortunately, high prices for seedling and grafted trees are limiting the development of a commercial pawpaw industry. Recent studies at Kentucky State University have developed recommendations (e.g., potting substrate type, the use of tall containers to accommodate the seedling's strong tap root, etc.) toward the successful container production of pawpaw (Finneseth et al., 1998a, 1998b; Jones et al., 1998; Layne, 1996; Pomper et al., 2002a, 2002b). However, further improvements in cultural methods for container production of robust pawpaw seedlings for grafting, transplanting to orchards, or home landscapes would be desirable.

There is little information available on the fertilization requirements of paw- paw. Slow-release fertilizers are an efficient means to meet the nutritional needs of container-grown nursery crops. Osmocote is a popular encapsulated, slow-release fertilizer that provides a relatively constant supply of nutrients for plant absorption over a fixed time frame. Because fertilizers such as Osmocote release nutrients slowly, they eliminate the need for labor-intensive liquid fertilization that may lead to excessive nutrient leaching and contamination of ground water (Nelson, 1998). Osmocote, alone or in combination with water-soluble fertilizer, has been used to successfully produce many tree species in containers. For example, false weymouth pine (Pinus pseudostrobus) and douglas pine (Pinus douglasiana) trees grew well when fertilized using Osmocote 14-14-14 at a rate of 4 $\mathrm{kg} \cdot \mathrm{m}^{-3}\left(6.74 \mathrm{lb} / \mathrm{yard}^{3}\right)$ (Mexal et al., 1995). River birch (Betula nigra), bald cypress (Taxodium distichum), sycamore (Platanus occidentalis), and weeping willow (Salix babylonica) have been grown successfully outdoors in containers with Osmocote 16-7-12 (16N$3.1 \mathrm{P}-10 \mathrm{~K})$ at a rate of $13 \mathrm{~kg} \cdot \mathrm{m}^{-3}(21.9$ lb/yard ${ }^{3}$ ) (Ruter, 1994). Green ash (Fraxinus pennsylvanica) and red oak (Quercus rubra) have been grown successfully in containers with Osmocote $18-6-12(18 \mathrm{~N}-2.6 \mathrm{P}-10 \mathrm{~K})$ at a rate of $3.6 \mathrm{~kg} \cdot \mathrm{m}^{-3}\left(6 \mathrm{lb} / \mathrm{yard}^{3}\right)$, supplemented with weekly applications of $200 \mathrm{mg} \cdot \mathrm{L}^{-1}$ $\mathrm{N}$ from 20-20-20 (20N-8.7P-16.6K) water soluble fertilizer (Arnold and Struve, 1989). Pomper et al. (2002b) found that pawpaw seedlings grew well in Pro-Mix BX potting substrate (Premier Horticulture, Inc., Red Hill, Pa.) with weekly liquid-feed applications of $500 \mathrm{mg} \cdot \mathrm{L}^{-1}$ Peters 20-20-20 watersoluble fertilizer plus soluble trace elements; however, further examination of specific nutritional requirements for container production of pawpaw seedlings could lead to enhanced growth of seedlings.

The objective of this study was to examine early growth and development of greenhouse-grown pawpaw seedlings with either slow-release fertilizer (Osmocote) as the sole fertilizer source or with Osmocote supplemented by water-soluble fertilizer, in an effort to determine the optimal fertilization for enhanced growth of pawpaw seedlings in containers.

\section{Materials and methods}

Plant material. For all experi- 
Table 1. Peters 20-20-20 (Peters) and Osmocote 14-14-14 (Osmocote) treatment levels used in experiments to enhance growth of pawpaw (Asiminatriloba) seedlings in containers.

\begin{tabular}{|c|c|c|c|}
\hline $\begin{array}{l}\text { Treatment } \\
\text { designations } \\
\text { (Peters level) }^{\mathrm{z}} \\
\end{array}$ & $\begin{array}{c}\text { Amount } \\
\text { applied } \\
{\left[\mathbf{m g} \cdot \mathbf{L}^{-1}(\mathbf{p p m})\right]}\end{array}$ & $\begin{array}{c}\text { Treatment } \\
\text { designations } \\
(\text { Osmocotelevel) })^{y}\end{array}$ & $\begin{array}{c}\text { Amount } \\
\text { applied } \\
\left(\mathbf{k g} \cdot \mathbf{m}^{-3}\right)\end{array}$ \\
\hline \multicolumn{4}{|c|}{ Expt. 1. Slow-release and weekly liquid-feed fertilizer application } \\
\hline Control & 0 & Control & $0.00^{\mathrm{x}}$ \\
\hline Medium & 250 & Low & 0.13 \\
\hline \multirow{9}{*}{ High } & 500 & Medium & 0.26 \\
\hline & & High & 0.81 \\
\hline & Expt. 2. Slow-rele & tilizer application or & \\
\hline & & Control & 0.00 \\
\hline & & A & 0.81 \\
\hline & & B & 2.22 \\
\hline & & $\mathrm{C}$ & 4.43 \\
\hline & & $\mathrm{D}$ & 8.86 \\
\hline & & $\mathrm{E}$ & 17.7 \\
\hline
\end{tabular}

zeters 20-20-20 (20N-8.7P-16.6K) water-soluble fertilizer plus soluble trace elements.

y Osmocote $14-14-14(14 \mathrm{~N}-6.1 \mathrm{P}-11.6 \mathrm{~K}) ; 3$ to 4 month release product.

${ }^{\mathrm{x}} 1 \mathrm{~kg} \cdot \mathrm{m}^{-3}=2.2 \mathrm{lb} /$ yard $^{3}$

Table 2. Leaf number and plant height of pawpaw (Asiminatviloba) seedlings grown in a greenhouse with three levels of soluble fertilizer [Peters 20-20-20 (Peters)] and four levels of slow-release fertilizer [Osmocote 14-14-14(Osmocote)].

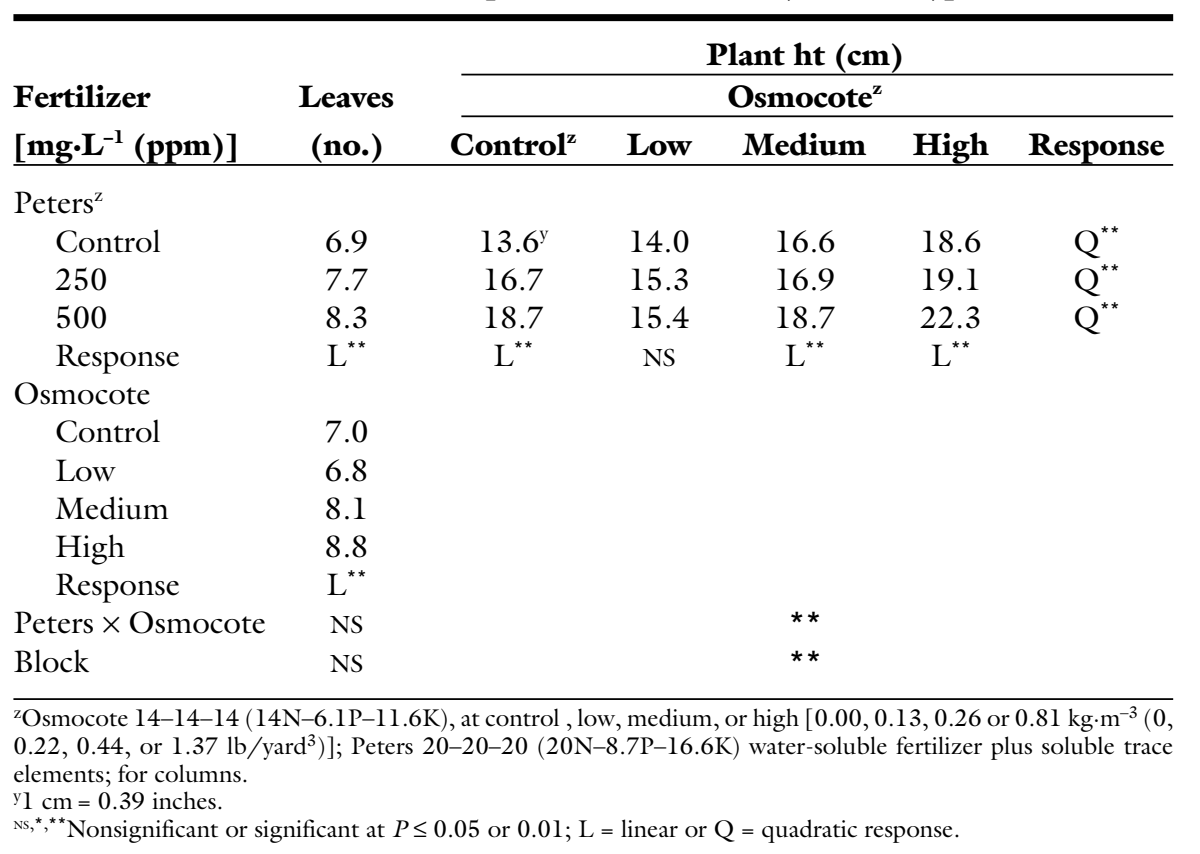

ments, pawpaw seed was harvested from open-pollinated half-sib trees at the Keedysville, Md., orchard at the Western Maryland Research and Education Center. Seed was stratified at 5 ${ }^{\circ} \mathrm{C}\left(4 \mathrm{l}^{\circ} \mathrm{F}\right)$ for 3 months and was sown to a 3 -cm (1.2-inch) depth in moist Pro-Mix BX potting substrate in $5 \times$ $6.4 \times 25.4-\mathrm{cm}(2 \times 2.5 \times 10$-inch $)$ Rootrainers (Hummert Intl., Earth City, Mo.) with a volume of $740 \mathrm{~cm}^{3}$ $\left(45\right.$ inch $\left.^{3}\right)$. The initial electrical conductivity (EC) of Pro-Mix BX substrate was determined to be 1.02 $\mathrm{dS} \cdot \mathrm{m}^{-1}$ and the nitrate $\left(\mathrm{NO}_{3}\right)$ concentration at $18 \mathrm{mg} \cdot \mathrm{L}^{-1}$ by the University of Kentucky Division of Regulatory Services (Lexington). Seedlings were grown in a white-washed glass greenhouse under a 16-h photoperiod supplemented by high-pressure sodium lights. At noon on a representative sunny day on 27 Apr. 2000, photosynthetic photon flux (PPF) was measured at $1200 \mu \mathrm{mol} \cdot \mathrm{m}^{-2} \cdot \mathrm{s}^{-1}$ at canopy level using a LI-185B photometer with a Q7072 quantum sensor (LI-COR, Inc., Lincoln, Nebr.) with the supplemental lights on.

EXPeriment 1. Slow-Release AND WEEKLY LIQUID-FEED FERTILIZER APPLICATION. A greenhouse experiment was conducted to examine early growth and development of containergrown pawpaw seedlings with both slow-release and weekly liquid-feed fertilizer applications. A split plot experimental design was used with main plots of three levels of liquid-feed fertilizer of 0 (control), 250, or 500 $\mathrm{mg} \cdot \mathrm{L}^{-1}$ Peters 20-20-20 (Peters) water-soluble fertilizer plus soluble trace elements (Scotts Co., Marysville, Ohio) that were applied once each week and subplot treatments at four levels of Osmocote 14-14-14 (Osmocote) 3to 4 -month release product (Scotts

Table 3. Growth characteristics of pawpaw (Asimina triloba) seedlings grown in a greenhouse with three levels of soluble fertilizer [Peters 20-20-20 (Peters)] and four levels of slow-release fertilizer [Osmocote 14-14-14 (Osmocote)].

\begin{tabular}{|c|c|c|c|c|c|c|c|c|c|c|}
\hline \multirow[b]{2}{*}{ Peters $^{\mathrm{y}}$} & \multicolumn{10}{|c|}{ Osmocote $^{\mathrm{z}}$} \\
\hline & Control & Low & Medium & High & Response & Control & Low & Medium & High & Response \\
\hline$\left[\mathrm{mg} \cdot \mathbf{L}^{-1}(\mathrm{ppm})\right]$ & \multicolumn{5}{|c|}{ Root dry wt (g) } & \multicolumn{5}{|c|}{ Shoot dry wt (g) } \\
\hline Control & $1.01^{\mathrm{x}}$ & 0.99 & 1.25 & 1.46 & $\mathrm{Q}^{* *}$ & 0.56 & 0.54 & 0.85 & 1.31 & $\mathrm{Q}^{* *}$ \\
\hline 250 & 1.06 & 1.20 & 1.44 & 1.42 & $Q^{\star *}$ & 0.89 & 0.84 & 1.05 & 1.71 & $\mathrm{Q}^{\star *}$ \\
\hline 500 & 1.25 & 1.05 & 1.61 & 1.56 & $\mathrm{Q}^{\star *}$ & 1.24 & 0.94 & 1.76 & 2.31 & $\mathrm{Q}^{\star *}$ \\
\hline Response & $\mathrm{L}^{*}$ & NS & $\mathrm{L}^{* *}$ & NS & & $\mathrm{L}^{* *}$ & $\mathrm{~L}^{* *}$ & $\mathrm{~L}^{* *}$ & $\mathrm{~L}^{* *}$ & \\
\hline Peters $\times$ Osmocote & & & ** & & & & & ** & & \\
\hline Block & & & ** & & & & & ** & & \\
\hline
\end{tabular}

${ }^{\mathrm{z}}$ Osmocote $14-14-14(14 \mathrm{~N}-6.1 \mathrm{P}-1 \mathrm{l} .6 \mathrm{~K})$, at control, low, medium, or high $\left[0.00,0.13,0.26\right.$ or $0.81 \mathrm{~kg} \cdot \mathrm{m}^{-3}\left(0.00,0.22,0.44\right.$, or $\left.\left.1.37 \mathrm{lb} / \mathrm{yard}{ }^{3}\right)\right]$

yPeters $20-20-20(20 \mathrm{~N}-8.7 \mathrm{P}-16.6 \mathrm{~K})$ water-soluble fertilizer plus soluble trace elements.

${ }^{\mathrm{x}} \mathrm{l} \mathrm{g}=0.035 \mathrm{oz}$.

Ns, ${ }^{* \star \star \star}$ Nonsignificant or significant at $P \leq 0.05$ or $0.01 ; \mathrm{L}=$ linear or $\mathrm{Q}=$ quadratic response. 
Co.) at 0 (control), $0.13,0.26$, or 0.81 $\mathrm{kg} \cdot \mathrm{m}^{-3}$; see Table 1 for treatment designations. Each subplot treatment consisted of a Rootrainer (27 cells) that contained Pro-Mix BX to which appropriate amounts of slow-release fertilizer had been incorporated. On 7 Feb. 2000, single seeds were sown into each cell of the Rootrainer so that in each of the three replicate blocks, 27 seeds were sown per treatment combination. A total of 972 seeds were sown ( 3 blocks $\times 3$ main plot treatments $\times 4$ subplot treatments $\times 27$ seeds $=972$ seeds). Seedlings were watered to saturation at least once each week, or as needed during the experiment. Ten weeks after sowing, on 17 Apr. 2000, when plants attained the two- to three-leaf stage, seed germination rate was recorded. At this time 10 uniform seedlings per experimental combination, or Rootrainer, were marked in each block, and leaf number and height were determined. Weekly fertilization treatments were also initiated at this time by manually saturating media with the appropriate liquid fertilizer; water used for preparation of the treatments had a total $\mathrm{N}$ content $\left[\mathrm{NO}_{3}\right.$ and ammonia $\left.\left(\mathrm{NH}_{4}\right)\right]$ of about $0.7 \mathrm{mg} \cdot \mathrm{L}^{-1}$ (Scott Laboratories, Allentown, Pa.). The number of leaves per plant and seedling height were recorded on 13 June 2000, 18 weeks after sowing, when plants were destructively harvested. Stems, leaves, and roots were oven-dried at $70{ }^{\circ} \mathrm{C}$ $\left(158^{\circ} \mathrm{F}\right)$ for $48 \mathrm{~h}$ and weighed. The greenhouse air temperature was measured every $30 \mathrm{~min}$ during the experiment using TEMP HOBO sensors (Onset Computer Corp., Pocasset, Mass.). Average greenhouse air temperatures $( \pm \mathrm{SE})$ were $25.1 \pm 0.1,31.3$ \pm 0.3 , and $34.0 \pm 0.7^{\circ} \mathrm{C},(77.2 \pm 0.1$, $88.3 \pm 0.3$, and $93.2 \pm 0.7^{\circ} \mathrm{F}$ ), at 0300 , 1200 , and $1600 \mathrm{HR}$, respectively.

EXPERIMENT 2. SLOW-RELEASE FERTILIZER APPLICATION ONLY. TO examine growth of container-grown pawpaw seedlings with slow-release fertilizer as the sole fertilizer source, a greenhouse experiment was conducted with six treatment levels of Osmocote at 0 (control), $0.81,2.22,4.43,8.86$, or $17.72 \mathrm{~kg} \cdot \mathrm{m}^{-3}$ (designated A to $\mathrm{E}$; see Table 1). A replicated block experimental design, with three replicate blocks, was used with each block containing each of the six treatments arranged randomly in each block. Each treatment in each block consisted of a Rootrainer (27 cells) containing ProMix BX to which appropriate amounts of slow-release fertilizer had been incorporated. On 30 June 2000, single seeds were sown into each cell of the Rootrainer so that in each of the three replicate blocks, 27 seeds were sown per treatment combination. A total of 324 seeds were sown ( 3 blocks $\times 4$ treatments $\times 27$ seeds $=324$ seeds sown). Seedlings were watered at least once each week to runoff, or as needed during the experiment. On 6 Sept. 2000,10 weeks after sowing, plants in all treatments had attained at least the two- to three-leaf stage, and seed germination rate was recorded. At this time, 10 uniform seedlings were marked, and leaf number and height were recorded. Thereafter, leaf number and height measurements were recorded weekly. The number of leaves per plant and seedling height were recorded on 26 Oct. 2000, 17 weeks after the initial height measurements, when plants were destructively harvested. Stems, leaves and roots were oven-dried at $70{ }^{\circ} \mathrm{C}\left(158^{\circ} \mathrm{F}\right)$ for $48 \mathrm{~h}$ and weighed. The greenhouse air temperature was monitored as described previously. Average greenhouse air temperatures $( \pm \mathrm{SE})$ were $23.5 \pm 0.1$, $29.1 \pm 0.3$, and $32.6 \pm 0.7^{\circ} \mathrm{C},(74.3 \pm$ $0.1,84.4 \pm 0.3$, and $\left.90.7 \pm 0.7^{\circ} \mathrm{F}\right)$, at 300,1200 , and $1600 \mathrm{HR}$, respectively, during the experiment.
Statistical analysis. Data were subjected to GLM analysis of variance and GLM regression analysis using the statistical program Costat (CoHort Software, Monterey, Calif.). Both linear and polynomial regression models were fit to the data and significance of the models determined. If linear regression models were significant, they are reported. If both linear and quadratic regression models were significant, then the quadratic model was reported.

\section{Results}

EXPeriment 1. Slow-RElease AND WEEKLY LIQUID-FEED FERTILIZER APPLICATION. No significant treatment differences were observed for seed germination percentage (average germination percentage was $70 \%$; data not shown). Analysis of variance indicated that there was a significant interaction between slow-release fertilizer rate and liquid-feed fertilizer regime main effects $(P<0.05)$ for plant height, root, shoot and total plant dry weight, and root:shoot ratio, but the interaction was not significant for seedling leaf number (Tables 2 and 3). Seedling leaf number showed a linear response to increasing rate of either liquid-feed Peters fertilizer or Osmocote, with the greatest leaf number at the highest treatment rates for both Peters and Osmocote (Table 2). Plant height showed a linear response to increasing rate of Peters in the control, medium, and high rates of Osmocote, with plants at $500 \mathrm{mg} \cdot \mathrm{L}^{-1}$ Peters with the greatest leaf number (see columns in Table 2 ). Plant height within each level of Peters showed a quadratic response to increasing rates of Osmocote, with the greatest plant height at the highest treatment rates for both Osmocote and Peters (see rows in Table 2). Root dry weight showed a linear response to increasing rate to Peters only in the

\begin{tabular}{|c|c|c|c|c|c|c|c|c|c|}
\hline \multicolumn{10}{|c|}{ Osmocote } \\
\hline Control & Low & Medium & High & Response & Control & Low & Medium & High & $\overline{\text { Response }}$ \\
\hline \multicolumn{5}{|c|}{ Total dry wt (g) } & \multicolumn{5}{|c|}{ Root to shoot ratio } \\
\hline 1.58 & 1.54 & 2.10 & 2.95 & $\mathrm{~L}^{* *}$ & 1.95 & 1.92 & 1.64 & 1.10 & $\mathrm{~L}^{* *}$ \\
\hline 1.96 & 2.04 & 2.49 & 3.25 & $\mathrm{~L}^{* *}$ & 1.22 & 1.55 & 1.42 & 0.85 & $Q^{* *}$ \\
\hline 2.49 & 2.00 & 3.37 & 3.53 & $\mathrm{~L}^{* *}$ & 1.08 & 1.24 & 0.91 & 0.67 & $\mathrm{Q}^{*}$ \\
\hline \multirow[t]{3}{*}{$\mathrm{L}^{* *}$} & & $\mathrm{~L}^{* *}$ & $\mathrm{~L}^{* *}$ & & $\mathrm{Q}^{* *}$ & $\mathrm{~L}^{* *}$ & $\mathrm{~L}^{\star *}$ & $\mathrm{~L}^{* *}$ & \\
\hline & $Q^{* *}$ & * * & & & & & ** & & \\
\hline & & ** & & & & & ** & & \\
\hline
\end{tabular}



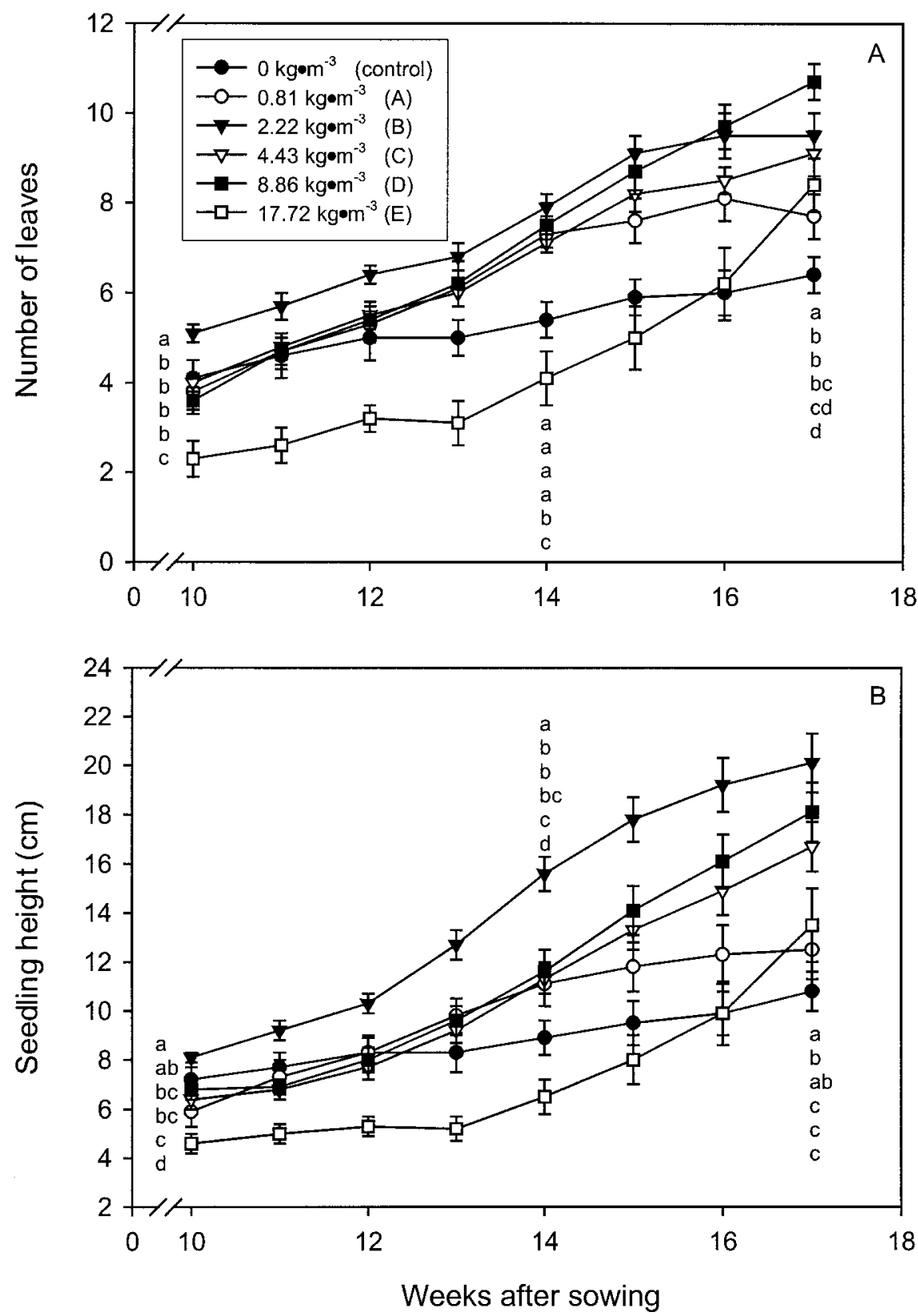

Fig. 1. Response of pawpaw (Asimina triloba) seedlings to Osmocote 14-1414(14N-6.1P-11.6K) slow-release fertilizerincorporated in the potting substrate at different rates for seedling leafnumber (A) and seedling height (B) 10 to 17 weeks after sowing. Letters correspond to treatment means that were significantly different byleast significant difference $(P<0.05)$ at each date; 1 $\mathrm{kg} \cdot \mathrm{m}^{-3}=2.2 \mathrm{lb} /$ yard $^{3}, 1 \mathrm{~cm}=0.39$ inches.

control and medium Osmocote treatment rate, with the greatest root dry weight occurring at $500 \mathrm{mg} \cdot \mathrm{L}^{-1}$ Peters (see columns in Table 3 ). Root dry weight within each level of Peters showed a quadratic response to increasing rate of Osmocote, with the greatest root dry weight at the me- level of Peters showed a linear response to increasing rates of Osmocote, with the greatest total plant dry weight at the highest treatment rates of Osmocote and Peters. Root to shoot ratio showed a quadratic response in the Osmocote control, and a linear response at the low, medium, and high treatment rates of Osmocote, to increasing rates of Peters. Root to shoot ratio within each level of Peters showed a linear response to increasing treatment rate of Osmocote without Peters application, with the lowest root to shoot ratio at the high treatment rate of Osmocote. Root to shoot ratio in either the 250 or $500 \mathrm{mg} \cdot \mathrm{L}^{-1}$ Peters treatment levels showed a quadratic response to increasing rate of Osmocote, with the lowest root to shoot ratio $(0.67)$ at the highest treatment rates of both Peters and Osmocote.

EXPeriment 2. Slow-release FERTILIZER APPLICATION ONLY. No significant treatment differences were observed for seed germination percentage (average germination percentage was $70 \%$; data not shown). Note that treatment $\mathrm{A}$ for Osmocote in this experiment is the same rate as the high rate of $0.81 \mathrm{~kg} \cdot \mathrm{m}^{-3}$ used in the slowrelease and weekly liquid-feed fertilizer application experiment described previously. Seedling emergence and growth, based on leaf number at 10 weeks after sowing, were hastened in treatment $\mathrm{B}$ and delayed in treatment E (Fig. 1A). Thirteen weeks after sowing, seedling leaf number in all other treatments was similar to that in treatment B, except for seedlings in treatment $E$ which had two to three leaves where seedling in all other treatments had four to five leaves. When seedlings were harvested 17 weeks after sowing, plants in treatment $\mathrm{D}$ had the highest leaf number and control plants had the lowest number. Seedlings in treatment $\mathrm{E}$ had accelerated growth over the last 3 weeks of culture, finishing with a similar number of leaves to those in treatments $\mathrm{C}$ and $\mathrm{D}$.

Seedling height, 10 weeks after sowing, was about $4 \mathrm{~cm}$ (1.6 inches) in treatment $\mathrm{E}$; seedlings had already reached a height of about $8 \mathrm{~cm}(3.1$ inches) in treatment B and about 6.5 $\mathrm{cm}$ (2.6 inches) in all other treatments by this time (Fig. 1B). Thirteen weeks after beginning measurements, seedling heights obtained with treatment E were lowest, whereas heights for 

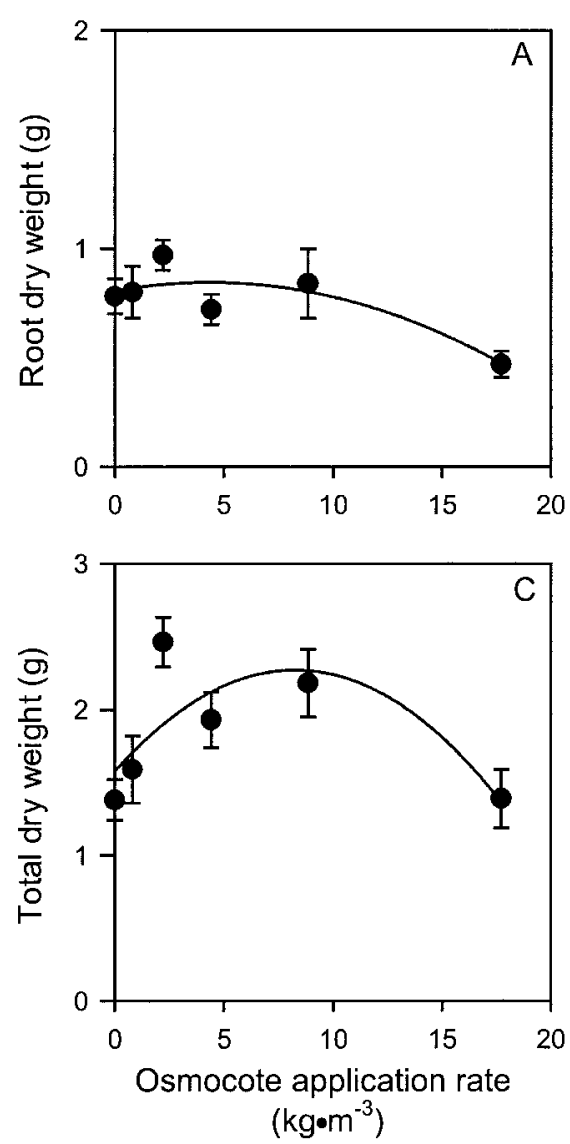

Fig. 2. The influence of Osmocote 1414-14(14N-6.1P-11.6K) slow-release fertilizer rates on biomass production by container-grown pawpaw (Asimina triloba) seedlings in a greenhouse. (A) root dry weight $(y=0.805+0.018 x-$ $\left.0.002 x^{2}, R^{2}=0.74, P=0.001\right)$, (B) shoot root dry weight $(y=0.768+0.148 x-$ $\left.0.008 x^{2}, R^{2}=0.58, P=0.001\right),(C)$ total plant dry weight $(y=1.577+0.167 x-$ $\left.0.010 x^{2}, R^{2}=0.58, P=0.001\right),(D)$ root:shoot ratio $(y=1.210+0.142 x-$ $\left.0.007 x^{2}, R^{2}=0.65, P=0.001\right)$. Each symbol is the mean of threeblocks, $\pm S E$; $1 \mathrm{~kg} \cdot \mathrm{m}^{-3}=2.2 \mathrm{lb} /$ yard $^{3}, 1 \mathrm{~g}=0.035 \mathrm{oz}$.

treatment B were greatest. At harvest, seedling heights in treatment $\mathrm{B}$ were still the greatest; however, seedlings at treatment $\mathrm{E}$ had grown more rapidly during the final 3 weeks and attained a height similar to those in the control and treatment $\mathrm{A}$.

At the termination of the experiment, shoot, root, and total plant dry weight showed a quadratic response curve to increasing rates of Osmocote (Fig. 2). Plants had the greatest shoot, root, and total plant dry weight in treatment B (Fig. 2A, 2B, and 2C). Root to shoot ratio showed a quadratic response curve, in which the root to shoot ratio decreased from about 1.5 with no Osmocote applied,
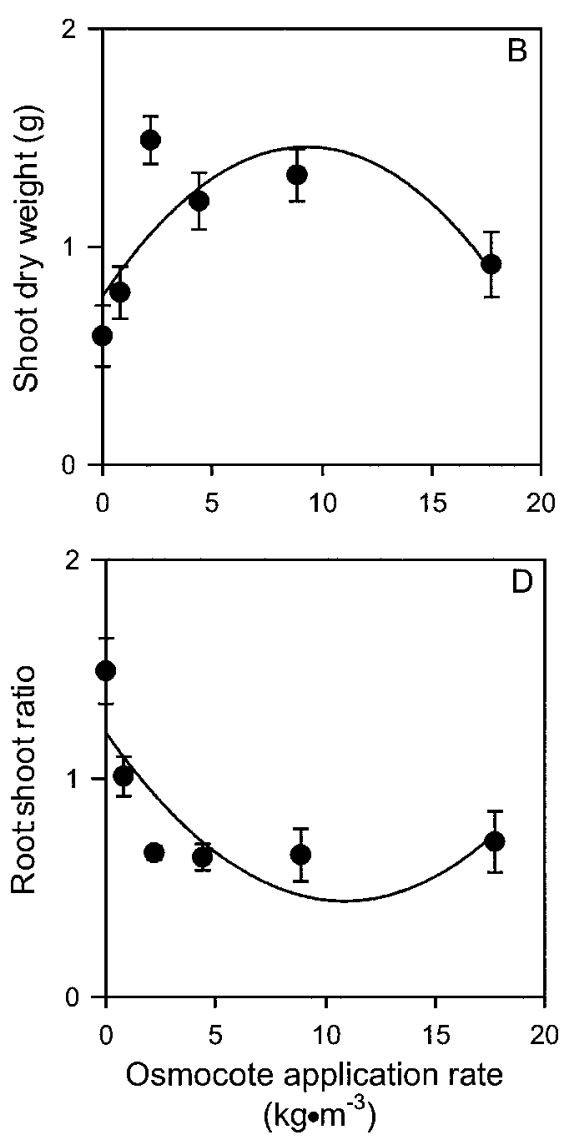

to about 0.65 with Osmocote at rates at or exceeding $2.22 \mathrm{~kg} \cdot \mathrm{m}^{-3}$ (Fig. 2D).

\section{Discussion}

Based on the results of this study, the 4-month formulation of Osmocote 14-14-14 can be used effectively as the sole fertilizer source at treatment rate $\mathrm{B}\left(2.22 \mathrm{~kg} \cdot \mathrm{m}^{-3}\right)$ or at the lower treatment rate $\mathrm{A}\left(0.81 \mathrm{~kg} \cdot \mathrm{m}^{-3}\right)$, which was the high rate in the first experiment, when supplemented with weekly applications of $500 \mathrm{mg} \cdot \mathrm{L}^{-1}$ of Peters 20-20-20 liquid-feed fertilizer for enhanced production of pawpaw seedlings in containers. Pawpaw seedlings responded well even to low rates of fertilization with Osmocote or Peters with enhanced growth. When plants in the slow-release and liquid-feed fertilizer application experiment were fertilized with the high rate of Osmocote $\left[0.81 \mathrm{~kg} \cdot \mathrm{m}^{-3}\left(1.37 \mathrm{lb} /\right.\right.$ yard $\left.\left.^{3}\right)\right]$, and $500 \mathrm{mg} \cdot \mathrm{L}^{-1}$ liquid-feed fertilizer, total plant dry weight $[3.53 \mathrm{~g}(0.12 \mathrm{oz})]$ was greater than that $[2.46 \mathrm{~g}(0.09$ oz)] of plants in sole slow-release fertilizer application experiment receiving treatment B of Osmocote as the sole fertilizer application. Control seedlings were similar in total dry weight in both Expt. 1 and Expt. 2. In the slowrelease and liquid-feed fertilizer ap- plication experiment, plants fertilized with the high rate of Osmocote $(0.81$ $\mathrm{kg} \cdot \mathrm{m}^{-3}$ ) and seven weekly applications of $500 \mathrm{mg} \cdot \mathrm{L}^{-1}$ Peters liquid-feed fertilizer received a total of $116 \mathrm{mg}(0.004$ $\mathrm{oz})$ of $\mathrm{N}$, whereas $230 \mathrm{mg}(0.008 \mathrm{oz})$ of $\mathrm{N}$ was supplied to plants in the sole slow-release fertilizer application experiment that received treatment rate $\mathrm{B}$ of Osmocote as their only fertilizer amendment. Thus, the greater total plant dry weight of seedlings in Expt. 1, fertilized with the high rate of Osmocote $\left[0.81 \mathrm{~kg} \cdot \mathrm{m}^{-3}\right.$ and $500 \mathrm{mg} \cdot \mathrm{L}^{-1}$ liquidfeed fertilizer, than in seedlings in Expt. 2 , fertilized solely with treatment rate $\mathrm{B}$ of Osmocote, was achieved even though the plants in Expt. 1 received only about $50 \%$ as much total $\mathrm{N}$ as plants in treatment $\mathrm{B}$. The greenhouse environment was warmer during Expt. 1 than during Expt. 2, which may have promoted growth of the seedlings during the former experiment. The warmer greenhouse temperatures may have promoted greater nutrient release rates by the Osmocote; however, since higher nutrient treatment rates in the slow-release fertilizer application only experiment did not enhance growth further, the warmer temperatures in the earlier experiment likely resulted in greater plant biomass accumulation by stimulating plant growth and nutrient uptake. Pomper et al. (2002b) found that bottom heat [32 $\left.{ }^{\circ} \mathrm{C}\left(90{ }^{\circ} \mathrm{F}\right)\right]$ increased total pawpaw seedling dry weight by $87 \%$ compared to plants grown at ambient root-zone conditions $\left[24^{\circ} \mathrm{C}\left(75^{\circ} \mathrm{F}\right)\right]$. Other differences in the cultural conditions during the experiments could also have affected plant growth; spring PPF may have been lower than summer levels. Seedlings grown at either the high rate of Osmocote $\left(0.81 \mathrm{~kg} \cdot \mathrm{m}^{-3}\right)$, supplemented with $500 \mathrm{mg} \cdot \mathrm{L}^{-1}$ Peters liquidfeed fertilizer, or Osmocote in treatment $B$ had similar root to shoot ratios of about 0.65 , indicating that both these fertilizer regimes resulted in excellent seedling shoot production.

Finneseth et al. (1998a) reported that early pawpaw seedling development can be divided into four distinct stages, including radicle protrusion, hypocotyl emergence, epicotyl elongation, and seedcoat abscission. At the time of epicotyl elongation, which can be more than $50 \mathrm{~d}$ after sowing, the radicle and developing root system can comprise up to $81 \%$ of the seedling biomass. When plants were grown with 
Osmocote incorporated in the potting substrate as the sole fertilizer source, seedling emergence and growth were hastened in treatment $\mathrm{B}$, compared to that of control plants. This was likely the result of the acceleration of the four stages of seedling development due to Osmocote being incorporated in the substrate. The highest treatment rate $\mathrm{E}$ inhibited plant growth, indicating that the nutrient levels at this rate were actually above what the plants prefer or that soluble salt levels in the substrate at this fertilization rate may have been too high. Electrical conductivity of the substrate was not measured during the experiment. At harvest, seedlings in treatment B were still tallest; however, seedlings in treatment $\mathrm{E}$ demonstrated accelerated growth 12 weeks after sowing and attained a height similar to those in the control and treatment A.

Hershey and Paul (1983) and Raither and Frink (1989) both reported that leaching of nutrients from slow-release fertilizer was highest during the early part of the growing season. It would seem likely that plant growth in treatment $\mathrm{E}$ accelerated as Osmocote nutrients and/or soluble salts were leached from the substrate; thereby, reducing the nutrient levels in the substrate and promoting growth of the seedlings. Tall containers are used in the production of pawpaw seedlings in order to accommodate the strong taproot produced (Layne, 1996). Further studies to determine the effect of the placement of slowrelease fertilizer application in containers (incorporated uniformly throughout the container versus topdressing) on nutrient leaching and pawpaw seedling growth would be desirable. More frequent application of smaller quantities of slow-release fertilizer and placement in the container could also be helpful to reduce nutrient leaching; however, this would result in additional labor costs. The Peters 20-20-20 plus soluble trace elements used in this study contained $3.9 \%$ ammoniacal $\mathrm{N}, 6.1 \% \mathrm{NO}_{3}-\mathrm{N}$, and $10.0 \%$ urea $\mathrm{N}$, whereas Osmocote 14-14-14 contained $8.2 \%$ ammoniacal $\mathrm{N}, 5.8 \% \mathrm{NO}_{3}-\mathrm{N}$, and no urea. Ammonia and urea need to be converted to $\mathrm{NO}_{3}$ to be taken up by the plant. Further studies would be required to determine if pawpaw seedlings prefer a particular form of $\mathrm{N}$ and whether the $\mathrm{N}$ form in the fertilizer formulations used in these experiments affected pawpaw growth. The $\mathrm{pH}$ and soluble salt concentration of potting substrate that has been amended with high rates of Osmocote and the influence of these parameters on pawpaw growth in containers should also be examined further.

In conclusion, the slow-release fertilizer Osmocote 14-14-14 can be used effectively as a sole fertilizer source at treatment rate $\mathrm{B}\left(2.22 \mathrm{~kg} \cdot \mathrm{m}^{-3}\right)$ or at a reduced rate of Osmocote, treatment rate $\mathrm{A}\left(0.81 \mathrm{~kg} \cdot \mathrm{m}^{-3}\right)$, when supplemented with weekly applications of $500 \mathrm{mg} \cdot \mathrm{L}^{-1}$ of Peters $20-20-20$ liquid-feed fertilizer to enhance production of pawpaw seedlings in containers.

\section{Literature cited}

Arnold, M.A. and D.K. Struve. 1989. Growing green ash and red oak in $\mathrm{CuCO}_{3}$ treated containers increase root regeneration and shoot growth following transplant. J. Amer. Soc. Hort. Sci. 114:402406.

Finneseth, C.L.H., D.R. Layne, and R.L. Geneve. 1998a. Morphological development of pawpaw [Asimina triloba (L.) Dunal] during seed germination and seedling emergence. HortScience 33:802-805.

Finneseth, C.L.H., D.R. Layne, and R.L. Geneve. 1998b. Requirements for seed germination in North American pawpaw [Asimina triloba (L.) Dunal]. Seed Sci. and Technol. 26:471-480.
Hershey, D.R. and J.L. Paul. 1983. Leaching-losses from pot chrysanthemums with controlled-release or liquid fertilization. Scientia Hort. 13:173-179.

Jones, S.C, R. N. Peterson, T. Turner, K.W. Pomper, and D. R. Layne. 1998. Pawpaw planting guide: Cultivars and nursery sources. KSU Pawpaw Ext. Bul. 001.

Layne, D.R. 1996. The pawpaw [Asimina triloba (L.) Dunal]: A new fruit crop for Kentucky and the United States. HortScience 31:777-784.

Mexal, J.G., R. Phillips, and R. Neumann. 1995. Mexican conifers' response to fertilizer type indicates difference between value and cost. Tree Planter's Notes 46:126129.

Nelson, P.V. 1998. Greenhouse operation and management. Prentice-Hall, Inc. Upper Saddle River, NJ.

Pomper, K.W., D.R. Layne, and R.N. Peterson. 1999. The pawpaw regional variety trial, p. 353-357. In J. Janick (ed.). Perspectives on new crops and new uses. ASHS Press, Alexandria, Va.

Pomper, K.W., D.R. Layne, and S.C. Jones. 2002a. Incident irradiance and cupric hydroxide container treatment effects on early growth and development of containergrown pawpaw seedlings. J. Amer. Soc. Hort. Sci. 127:13-19.

Pomper, K.W., D.R. Layne, S.C. Jones, and M.G. Kwantes. 2002b. Growth enhancement of container-grown pawpaw seedlings as influenced by media type, rootzone temperature, and fertilization regime. HortScience 37:329-333.

Raither, T.M. and C.R. Frink. 1989. Nitrate in runoff water from container grown juniper and Alberta spruce under different irrigation and $\mathrm{N}$ fertilization regimes. J. Environ. Hort. 7:32-35.

Ruter, J.M. 1994. Growth responses of four vigorous-rooted tree species in cupric hydroxide-treated containers. HortScience 29:1089. 